\title{
Carcinoma of the Conjunctiva pT4a TNM
} Finding v7

National Cancer Institute

\section{Source}

National Cancer Institute. Carcinoma of the Conjunctiva pT 4a TNM Finding v7. NCI

Thesaurus. Code C88597.

Carcinoma of the conjunctiva with tumor invading the orbital soft tissues, without bone invasion. (from AJCC 7th Ed.) 